\title{
EVOLUTION OF THE C-IED STAFF OFFICERS COURSE
}

\author{
A C-IED TÖRZSTISZTI TANFOLYAM FEJLŐDÉSE
}

\author{
TÁBI Levente \\ (ORCID: 0000-0003-0130-9248) \\ tabi.levente@uni.nke.hu
}

\begin{abstract}
At the beginning of the XXI century the Countering Improvised Explosive Devices (CIED) tasks became very important in NATO missions. Every $C$-IED related mission is connected to the three essential C-IED pillars (Attack the Networks, Defeat the Device and Prepare the Force). Since 2010; when the CIED COE was established in Madrid, Spain; $C$ IED COE has taken on a significant role in the NATO's C-IED Education \& Training activities. One of its main tasks is to prepare, provide, run and lead different $C$-IED courses.

The C-IED staff course is a very important part in the C-IED education and training landscape. This kind of staff course evolution and development is always based on the current IED threat and the NATO requirements. Updating the existing course materials and lectures or developing brand new courses are significant issues for which, over the past few years, the C-IED COE has been recognized, even to the point of taking over these responsibilities to support NATO, Allied and partner nations.
\end{abstract}

Keywords: NATO, C-IED COE, C-IED staff course

\begin{abstract}
Absztrakt
A XXI. század elejétöl az Improvizált Robbanóeszközök Elleni Védelem feladatainak végrehajtása nagyon fontos részét képezték a NATO misszióknak. Minden C-IED-vel kapcsolatos feladat a C-IED három alap-pilléréhez (Hálózat Elleni Tevékenység, Eszközök Megsemmisitése, Erök Felkésztése) kapcsolható. A C-IED Kiválósági Központ 2010-es megalakitása óta nagyon fontos szerepet vállalt magára a C-IED képzés és kiképzés területén. A központ egyik legfontosabb feladata, hogy összeállítson, megszervezzen és levezessen különböző $C$ IED tanfolyamokat.

A C-IED törzstiszti tanfolyam egy nagyon fontos része a C-IED képzési és kiképzési rendszerének. Ennek a törzstanfolyamnak a megalkotása és fejlődése mindig az adott IED veszélyhelyzet, valamint a NATO müveleti követelmények alapján került kialakitásra. $A$ meglévő tanfolyamok naprakészen tartása vagy teljesen új tanfolyamok létrehozása egy szignifikáns feladat, melynek felelősségét az elmúlt évek folyamán a C-IED COE átvette, ezzel is támogatva a NATO-t, a szövetség tagországait, illetve partner nemzeteit.
\end{abstract}

Kulcsszavak: NATO, C-IED COE, C-IED törzstanfolyam 
"If your vision is one year, plant crops

If your vision is ten years, plant trees

If your vision is one hundred years, teach people"

(African ancient sayings) [1]

\section{INTRODUCTION}

According to the C-IED ${ }^{1}$ doctrine, the AJP-3.15 ${ }^{2}$ [2] and the C-IED strategy of training, education and skill development, courses are among the key elements for fighting against the IED $^{3}$ system. One of the main pillars of the C-IED mission is to Prepare the Force ${ }^{4}$, meaning that for NATO it is very important to have educated, trained, skilled and experienced members in the staff and units who are able to manage, coordinate, support or simply recommend the CIED solutions, tasks for NATO, national unit, headquarters ${ }^{5}$ or missions. [9]

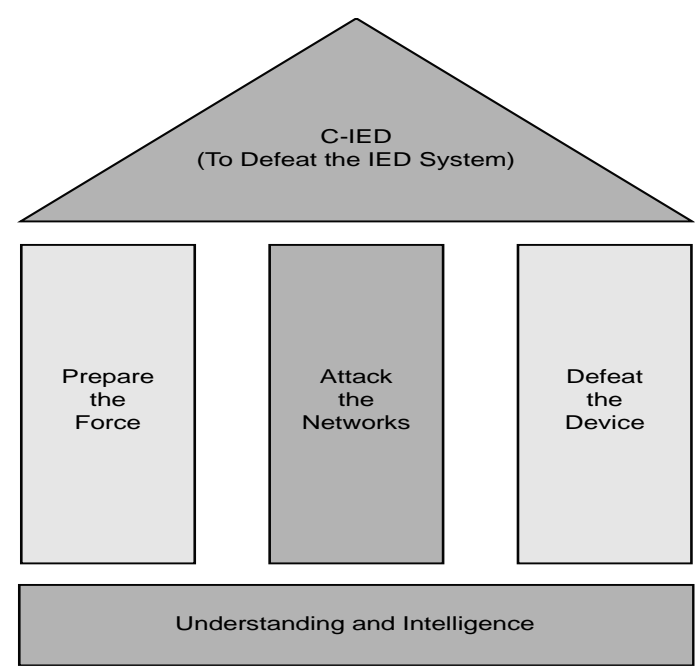

Figure 1 - The C-IED Approach with Supporting Activity Pillars [3, p. 1-2]

Preparing the units and HQ for the C-IED fight is a very complex mission because it must start from the individual training and education to carrying out a complex exercise, such as collective training, for units and HQs. Moreover, these individual and complex training tasks should be completed at all levels, from the very tactical, technical knowledge up to the high military strategic level and even up to the political level.

Training requirements are established by the national authorities or NATO. Obviously, each level has desired end state, required outcome and in an ideal situation in which we can establish a clear hierarchy and linkage to the different C-IED related education and training events, as can be seen in the Figure 2.

\footnotetext{
${ }^{1}$ C-IED - Countering Improvised Explosive Devices [4]

${ }^{2}$ AJP-3.15 - Allied Joint Publication-3.15 (Allied Joint Doctrine for Countering Improvised Explosive Devices)

${ }^{3}$ IED - Improvised Explosive Device [4]

${ }^{4}$ The "Prepare the Force", the "Attack the Networks" and the "Defeat the Device" are the three main pillars for fighting against the IED system. Underneath of these pillars there is with a supporting role, the "Understanding and Intelligence".[2, p. 1-5, 2-1]

${ }^{5} \mathrm{HQ}$ - headquarters [4]
} 


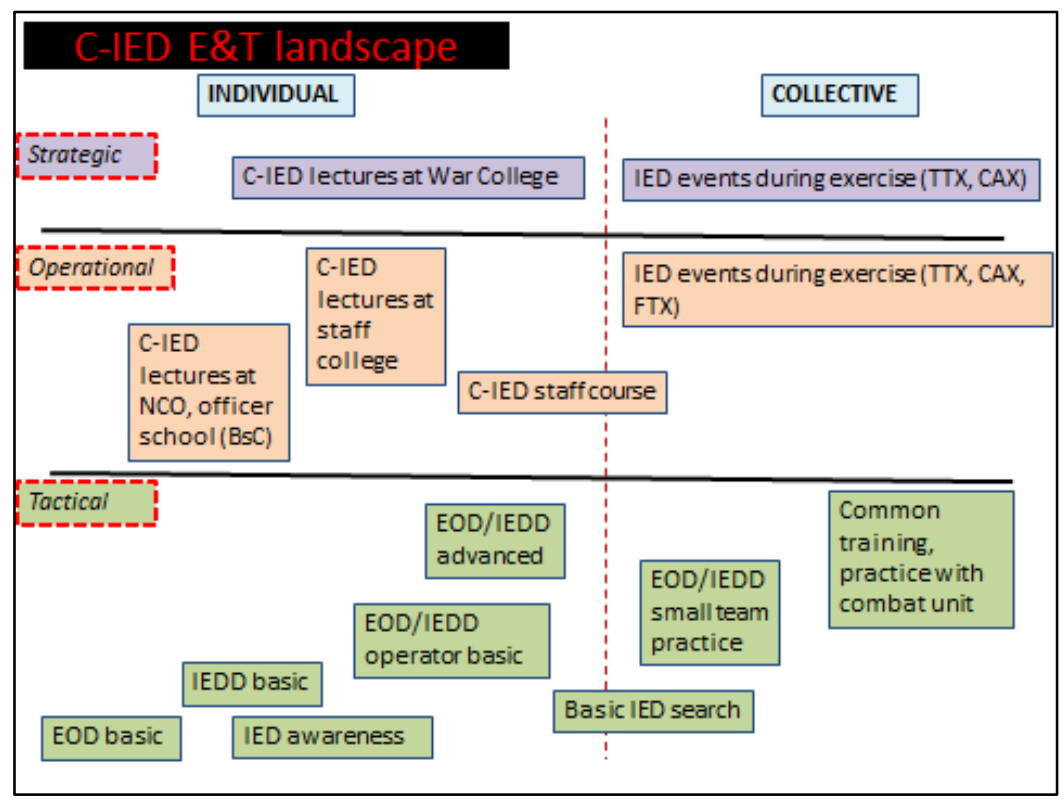

Figure 2 - Fictitious theoretical C-IED Education and Training landscape (Created by the author)

The Counter Improvised Explosive Devises Centre of Excellence ${ }^{6}$ is one of the main organizations in NATO in charge of developing, evaluating and facilitating different C-IED training opportunities. According to the multiple requirements, nowadays, the focal point for the C-IED COE is developing, facilitating and providing different, mainly operational level staff officer oriented courses. Due to the fact that recently there are multiple C-IED staff officers courses, in this article I would like to focus on and introduce the evolution of the C-IED staff course, so called "C-IED Staff Officers Course".

\section{C-IED COE/PTF $/$ C-IED DEPARTMENT HEAD}

The C-IED COE was established in 2010 and since then the C-IED effort is improving. Before the COE was created, NATO and some nations had already recognized the need for C-IED training. So when the C-IED COE was fully capable there were several, mainly basic level CIED trainings and also a few courses for staff members. Those NATO courses were developed by NATO $\mathrm{ACT}^{8}$ which had a C-IED team in charge of developing and running different C-IED training programs at that time. There were lots of initiatives and that team was able to develop, for instance, the "Weapon intelligence Team" course, the "C-IED Staff Officer Awareness Course ${ }^{" 10}$, etc.

The C-IED COE, in just a couple of years, was able to take over those courses from NATO ACT and also has slowly taken the leading role in "Prepare the Force" tasks. The main reason the C-IED COE took this lead was because in accordance with its mission $(, \ldots$ to provide subject matter expertise in order to support the Allied, its Partners, and the International Community in the fight against IED and co-operate to increase security of Allied Nations and

\footnotetext{
${ }^{6}$ Counter Improvised Explosive Devises Centre of Excellence (C-IED COE) was established in 2010 in Madrid, Spain. In the C-IED COE Spain is the framework nation and up to the end of 2018 there are additional 11 sponsoring nations (CZE, DEU, FRA, GRC, HUN, NLD, PRT, ROU, SWE, TUR and USA).

${ }^{7} \mathrm{PtF}$ - Prepare the Force [3, p. Lex-2]

${ }^{8}$ NATO ACT - NATO Allied Command Transformation [5]

${ }^{9}$ WIT - Weapon intelligence Team

${ }^{10}$ SOAC - C-IED Staff Officer Awareness Course
} 
also all the troops deployed in theatres of operations, reducing or eliminating the threats from improvised explosive devices used or for use....") [6] this is one of the main tasks of this organization.

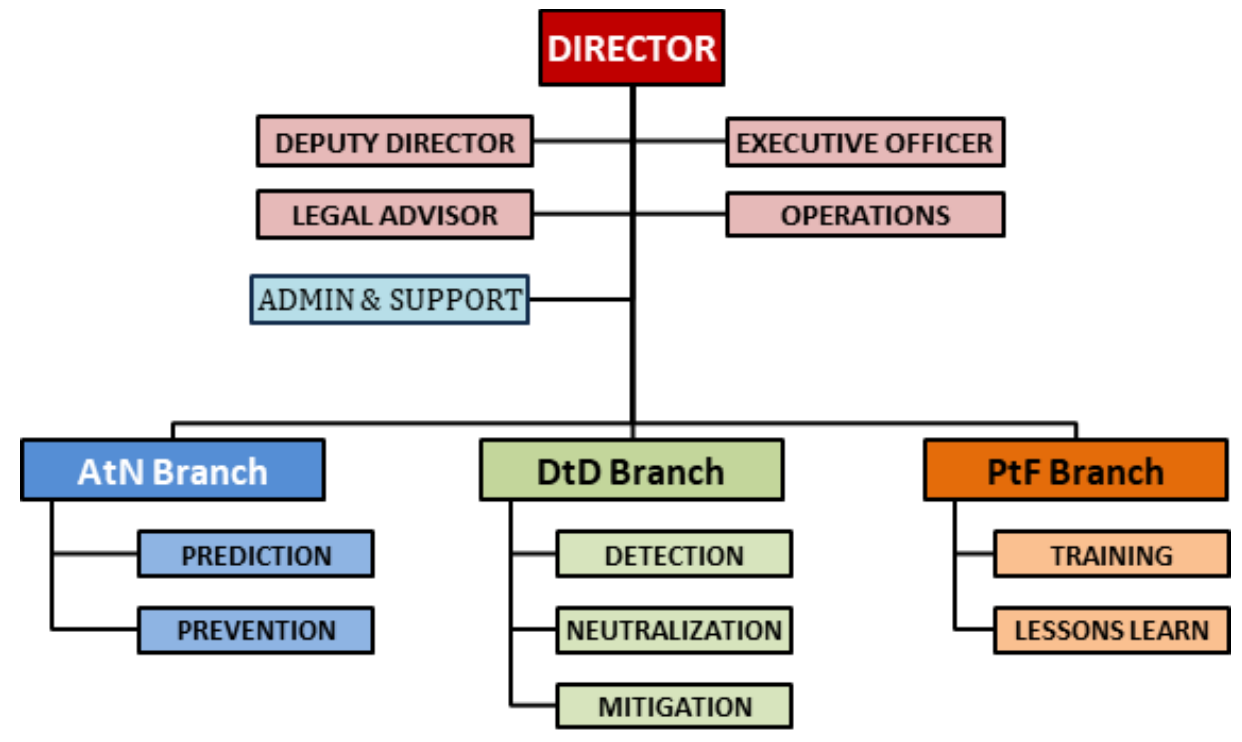

Figure 3 - The C-IED COE structure (Created by the author)

One of the C-IED COE branches is Prepare the Force which has been in charge, in the field of C-IED, of all education and training related tasks presented to the COE. Since NATO has established the "Requirement Authority" and the "Department Head" roles the C-IED COE PtF branch plays its role accordingly with responsibility of the C-IED Department Head in NATO. In 2016 the C-IED COE has also received the unconditional accreditation of quality assurance ${ }^{11}$ [7]. With this accreditation the C-IED COE is in charge of evaluating all C-IED courses in NATO and in accordance with the QA certification, without any questions, NATO certifies CIED courses according to the COE's recommendation. This provides the COE more possibilities, flexibility and obviously more responsibilities for the role of developing and monitoring high quality C-IED courses for NATO.

The SOAC course was so called the typical staff officer course at the beginning of the CIED COE's life. The aim of the course was (and still it is) to provide Brigade and Divisional Staff members an awareness of C-IED strategies and supporting activities that may need to be integrated into existing operational planning and structures. In other words, the SOAC gives staff personnel an overview of the phenomenon of the IED threat and provides some orientation tools regarding the C-IED approach necessary to successfully fight against the IED threat.[8, p. 1] This also means that the desired end-state of the course is that staff members at a tactical, operational level in HQ will get a deeper understanding of the IED weapon system, Attack the Networks ${ }^{12}$ enablers and activities that may be integrated into the existing operational planning and structures. According to the Bi-SC075-007, the level of knowledge of the SOAC is $100-$ Understand. [10, p. 97]

The ideal training audience should come from tactical and operational level staff, being staff officers (OF1-OF5) and Senior Non-Commissioned Officers (OR7 and above) [11, p. 1-2], experienced in intelligence and operational planning, and Information Operations. The ambition for the course has been to have approximately 150 students per year who may come

${ }^{11}$ QA - Quality Assurance [7]

${ }^{12}$ AtN - Attack the Networks [3, p. Lex-1] 
from NATO Command Structures, Allied and PfP (Partnership for Peace) partner Nations, and to those who foreseeably will be deployed to a NATO mission.

Altogether, for supporting those above mentioned intentions and requirements the following course structure was established. The SOAC duration has been established in 5 days. At the beginning, the course focusses mainly on theoretical lectures and towards the end of the week the focus shifts to more practical activities.
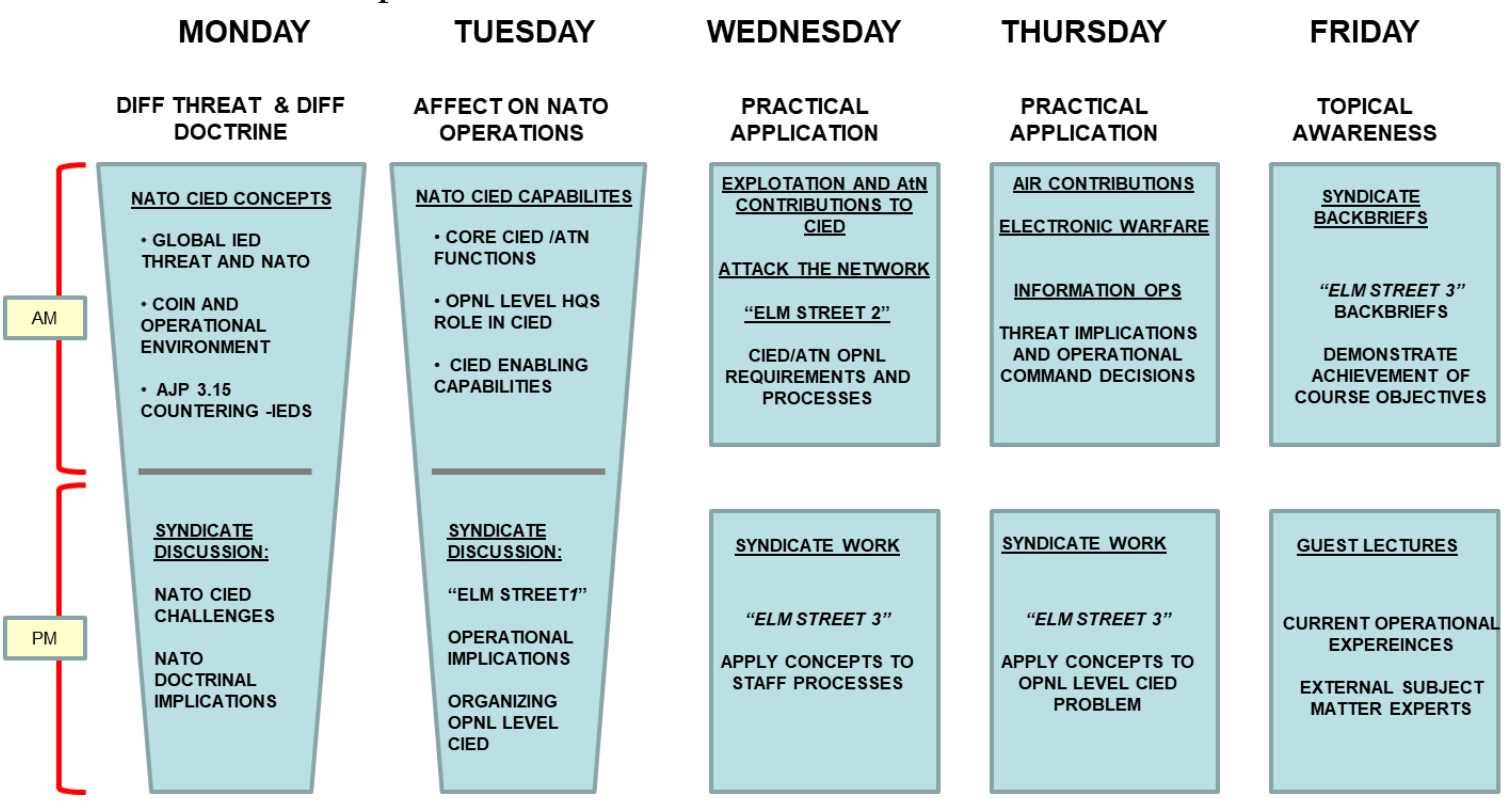

Figure 1 - SOAC agenda [12, slide\# 4$]^{13}$

Due to the fact that in 2011 and the following years the main operation for NATO was the ISAF $^{14}$ mission in Afghanistan, the main goal of the SOAC was to support NATO the best way possible in this operation. This was one of the reasons why in the agenda we could find classes as important as Counter Insurgence, Air Contribution, Electronic Warfare and Information Operation. The scenario of the practical exercises was also based on a peace keeping scenario, very much in line with the real life scenario in Afghanistan then.

During SOAC there were no tests or evaluation processes. The instructors and mentors would question the students and involve them in the class and syndicate work [8, p. 7] At the end of the course those students who had achieved the course objectives received a certificate stating that they successfully attended the SOAC.

Until 2014 the C-IED COE did not change anything in the program, only updated the lectures. The C-IED COE would keep the SOAC, as one of the main courses in NATO for countering the IED threat. In 2014 the C-IED COE received a request from the $\mathrm{UN}^{15}$ to conduct a staff course in Mali on the subject of C-IED. For the PtF branch of the COE the most logical solution was to use the proven SOAC. However, this course had been developed for NATO and PfP nations ${ }^{16}$, but it was not complicated to adapt the content and make the requested staff

\footnotetext{
${ }^{13}$ The SOAC agenda, as usual task before starting any courses, should have been revised and updated by the assigned Course Director. The Course Director's responsibility and task is to make it sure that the course is going to be coherent and fit to the requirements.

${ }^{14}$ ISAF - International Security Assistance Force, NATO mission in Afghanistan the period of 2001-2014.

${ }^{15} \mathrm{UN}$ - United Nations

${ }^{16} \mathrm{PfP}$ - The Partnership for Peace is a program of practical bilateral cooperation between individual partner countries and NATO. 21 Non-NATO nations are participating in NATO's PfP program.
} 
course available to the UN. The result of the transition was the "C-IED Awareness Course". ${ }^{17}$ This is the reason that we, in the C-IED COE, call this course "the younger brother of the SOAC".

While the classification of SOAC is NATO Secret [8, p. 5], the classification for CIAC is NATO Non-classified. [13, p. 1] The duration of the CIAC has not been fixed, so it can be from 3-5 days long. The structure of this non-class course is similar to the SOAC, however, it was created in a more flexible way. The main idea for the CIAC is that the COE may obviously deliver the NATO C-IED strategy, however, there is a possibility to discuss local or area of interest topics. Also it is important to point out that with the CIAC the COE never imposes the receiving nations, organizations to follow the NATO C-IED approach. Furthermore, one of the main goals of the CIAC is to facilitate those non-NATO partner nations and organizations the possibility to understand and apply the received NATO C-IED strategy and incorporate them into their own capabilities.

Since the CIAC has been developed, this course has been conducted for UN attendees in Mali, for Ukrainian Security Forces in Ukraine and for Jordanian Security Forces in both the C-IED COE in Madrid and in Jordan, as well. We, in the C-IED COE, believe that this course is really useful and unique in the field of C-IED education and training and owes much of its success to the flexibility of its contents.

We can also say that the SOAC has been a very successful course. Proof of this is that as many as 564 students from 35 countries ${ }^{18}$ have attended since it was first introduced. Furthermore, in the endorsed C-IED Discipline Alignment $\operatorname{Plan}^{19}$ of 2015, it is stated that the SOAC should be revised to cover the maritime domain and Joint Operational nature of the CIED. [14, p. 8] In the following years the C-IED COE revised the SOAC and developed a new C-IED staff officer course to support those new NATO requirements.

\section{CSOC DEVELOPMENT CSOC CCD, ACCREDITATION}

According to the DAP in 2015, during the revision process the COE training SMEs identified two ways to support the new requirements. One way was to create a brand new Advanced Staff Officers Course from scratch; the other was to upgrade the existing SOAC. Due to the fact the SOAC was tried and tested and proven successful, the COE recognized that the best way to meet NATO's new requirement was not to develop a new C-IED staff course from scratch but rather to use most of the content and structure of the existing SOAC.

One of the key issues was that this new course should cover the operational level planning considerations, should focus on the joint function and interagency approach in the C-IED field (maritime, law enforcement, etc.), and for the practical exercise perspective to use a complex, hybrid scenario. The result of the revision and the development was that new course content was developed with a few new lectures, and from the SOAC content some lectures were merged into one and some others were upgraded and updated, based on the more recent situation.

In April 2016 the C-IED COE ran a pilot version of the new course for C-IED staff members. Based on the invited attendees' comments and concerns, the result of this training solution was that the new C-IED staff officer course had been sufficient to substitute the SOAC, and the most of the content of this new course was mature enough to cover NATO's requirements.

\footnotetext{
${ }^{17}$ CIAC - C-IED Awareness Course

${ }^{18}$ The C-IED COE since took over the leadership and ownership of the SOAC created, maintained and updated a courses' statistics file. In this file all C-IED related courses, facilitated by the C-IED COE, every attendees in figures are registered. This data in the text comes from the version dated: 11 Oct 2018.

${ }^{19}$ DAP - Discipline Alignment Plan
} 
During the pilot course the participants agreed that the name of that new course is "C-IED Staff Officers Course" ${ }^{\text {20 }}$.

"The aim of this course is to provide C-IED Staff Officers and Senior Staff Assistants, at Upper Tactical and Operational levels, with the knowledge and skills to facilitate, manage and lead the C-IED effort." [15] This means that with this course the staff members in charge of dealing with C-IED during a mission could be prepared in general terms to be able to provide C-IED support to their commander. For this reason the training audiences were identified as mainly those Staff Officers and senior Staff Assistants (or equivalent civilians) who work in NATO or national operational HQ in the intelligence, operational, planning and training departments and governmental agencies in C-IED related positions.

According to the approved Course Control Document $\mathrm{II}^{21}$ the following performance objectives were declared [15]:

1. Understand the IED system/networks and the IED threat.

2. Understand the C-IED approach and the integration of C-IED into command operational design.

3. Understand C-IED planning and reporting considerations.

4. Understand the Attack the Networks operations in C-IED operations.

5. C-IED training and Lesson Learned.

For reaching these objectives the course has been designed as you can see in the Figure 5.

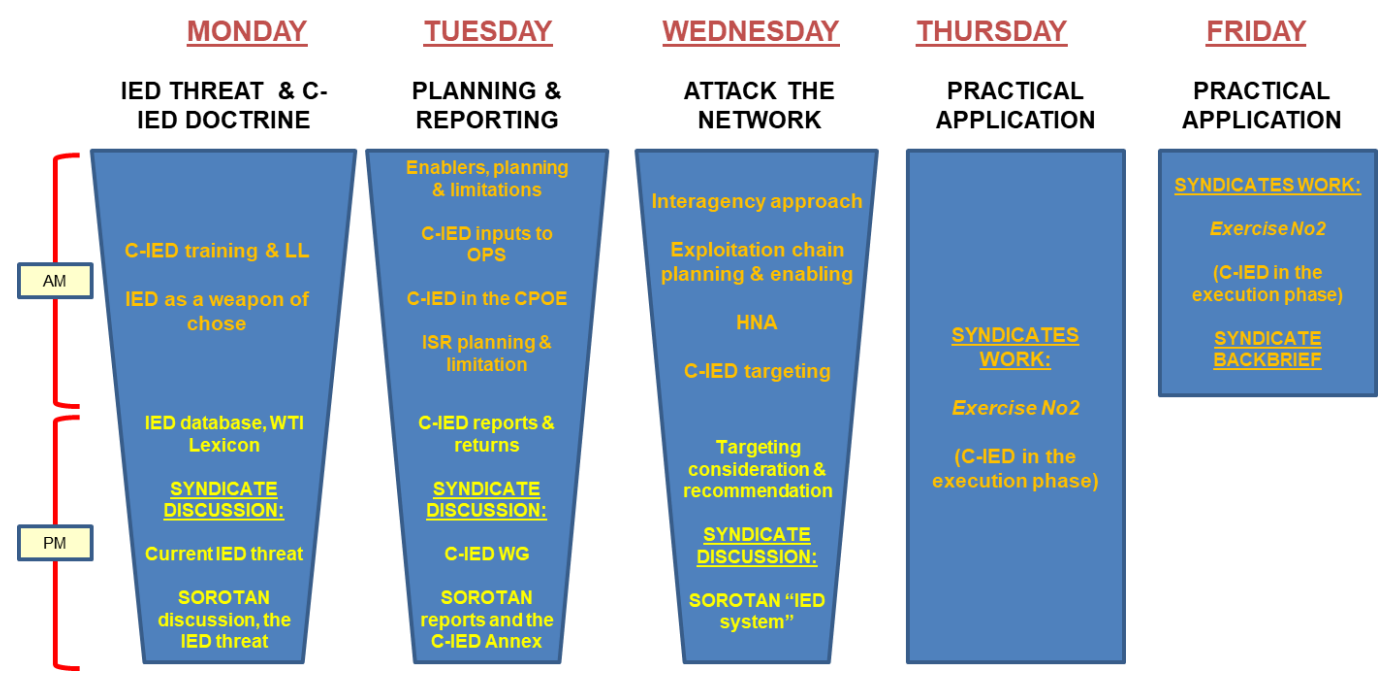

Figure 2 - CSOC Agenda, Iteration March 2017, (Created by the editor)

As you can see, the duration of the course is also 5 days and contains theoretical lectures and practical activities. The lectures and briefings are structured together based on the related subject they cover, which means that content-wise the theoretical classes are interconnected each day. Although most of the briefings do not contain classified information, due to the discussions and other sensitive topics, e.g. current IED trends and the IED systems, C-IED targeting, etc., the CSOC has NATO Secret classification. Because of this open discussions

\footnotetext{
${ }^{20}$ CSOC - C-IED Staff Officers Course

${ }^{21}$ CCD - Course Control Document "a set of documents used to define a NATO E\&IT solution based on an E\&IT requirement”. [10, p. B-2] Usually there are three CCD-s: CCD-I (CONTROL FORM); CCD-II (COURSE PROPOSAL); CCD-III (PROGRAMME OF CLASSES) [10, annex K, L and R]
} 
often pop up during the lectures and most of the attendees are open about sharing their personal and even national experience, point of views, etc.

Beside the redesigned CSOC, the C-IED COE has also developed an online course. With this Advanced Distance Learning 22 online course the selected attendees can increase their $\mathrm{C}$ IED knowledge before starting to the face to face CSOC. The online course, named " $A D L-207$ $C$-IED course" [16], is only open for the CSOC attendees, and it is a mandatory prerequisite course for them. During the online course the students must successfully pass several online exams to get the final certificate of accomplishment. [17]

Since the CSOC run, in the eight iterations, all together 195 attendees have been registered from multiple NATO organizations, allied and partner nations. If we look at that no more than three CSOC iterations per year are possible to be run at the C-IED COE venue, and there is a 24-seats per iteration limit, in order to ensure an adequate quality for the course, this figure is significantly high.

The lectures of the CSOC are delivered mostly by the COE staff members, nevertheless there are always external lecturers and mentors from different NATO, Allied nations and C-IED specialized organizations. Having external support also provides quality because those briefers can bring their current knowledge and C-IED experience. Another quality assurance aspect of this course was that it was designed not only to give a one way communication from the briefer to the audience but also, during the classes, to provide possibilities for discussion, and for sharing experiences among the attendees. Finally - after each iteration - the COE staff analyzed the attendees' feedback and comments, and all relevant issues, concerns were reconsidered, and the content of the lectures were amended and updated accordingly.

The SOAC, CIAC and CSOC are not the only staff courses developed and delivered by the C-IED COE's. Hereafter are some others [18]:

1. C-IED AtN Operational Course ${ }^{23}$ - this is a course oriented to Attack the Networks' tasks which mainly cover how to analyze, engage and target the IED system at operational level.

2. Attack the Networks Interagency Exploitation and Analysis ${ }^{24}$ - an upper tactical level course, where using real events and case studies, the training audience can discuss the lessons learnt and can analyze real events which took place in the past.

If we look to the future, although we can recognize that the current status and version of the C-IED staff courses is able to fulfil NATO's requirements, we cannot say that we have finished our job. The C-IED COE will continue to analyze the current IED threat throughout the world and update the contents of its courses based on these and information received, comments and feedback on courses delivered in order to ensure the continued quality of its courses.

If we look at the C-IED staff courses and their future, we can assume the following:

1. The C-IED COE most likely will not run the SOAC course anymore, as it is a bit outdated and in its current status and composition does not support the NATO and Allied nations requirements. On the other hand, my concern is that based on the lack of C-IED understanding at tactical level, the SOAC could be a good and relevant course for nations to train their tactical level staff members about the basics of $\mathrm{C}$ IED. For this purpose, the content should be revised, updated and the classification

\footnotetext{
${ }^{22}$ ADL - Advanced Distance Learning

${ }^{23}$ AtNOC - C-IED AtN Operational Course

${ }^{24}$ ATIX - Attack the Networks Interagency Exploitation and Analysis
} 
of the course also should be modified not to be higher than "NATO selected". Nevertheless, the SOAC should remain under the COE control for quality reasons.

2. The CSOC, as it is now and for the next couple of years, will support and meet the NATO requirements. The only thing the COE staff needs to do is to update according to the recent IED threat and NATO, adversary tactics, techniques and procedures.

3. The CIAC is a very flexibly structured course. Keeping this flexibility allows the COE staff the possibility to update and amend the content of the course based on the receiver nation, organization requirements and needs. This version of the C-IED staff course is very important to be kept for partner nations because it is very crucial to their C-IED development at staff levels.

4. The AtNOC is currently under revision. In previous years the duration of the course was only 5 days, the newly developed version has been extended by an additional week. The pilot course was delivered successfully and now the C-IED COE is analyzing which course composition provides better solution for the long-term point of view.

5. The ATIX is also under revision. The COE is evaluating different ways to move ahead. However, it is probably one of the courses which will be closed in the near future. Most likely that its lectures will be embedded into the existing courses, mentioned above.

\section{SUMMARY}

The NATO accredited C-IED Center of Excellence is that multinational organization whose role and responsibility is to provide support to NATO, Allied and partner nations, organizations whose mission is to fight against the IED threat all over the world. For this reason, the COE in its role of being the NATO C-IED Department Head - continuously analyzes the IED threat and provides recommendations, suggestions and solutions for its partners. One of the supports the C-IED COE provides is education and training solutions.

In recent years the COE has taken over already existing courses from different NATO organizations and has developed new courses, which are able to cover NATO's requirements, closing the training gaps. Different C-IED staff courses provide different training solutions.

In this article, my intention was to show what kind of C-IED staff courses have been developed in recent years and how the C-IED COE endeavors to find better solutions for requirements. The existing $\mathrm{C}$-IED course adequately covers the tactical and operational level needs for both NATO and allied nations and even for NATO's partner nations.

This initiative should be continued due the fact that the IED threat remains one of the major challenges for nations and for NATO and to fact that progress of the C-IED COE is good, appreciated and should continue to allow for well-educated and trained C-IED subject matter experts in the national and international staffs at all levels. 


\section{BIBLIOGRAPHY}

[1] NIEVES, M.: Understanding the Adult Learner, C-IED COE internal Train the Trainer training, C-IED COE, 13 September 2016, (lecture).

[2] AJP 3.15 (C), Allied Joint Doctrine for Countering Improvised Explosive Devices, Edition C Version 1, February 2018, Source:

https://nso.nato.int/protected/nsdd/ CommonList.html (date of downloading: 04 March 2018).

[3] ACIEDP-01, Countering Improvised Explosive Devices Training Requirements, Edition B, Version 1, November 2018, Source:

https://nso.nato.int/protected/nsdd/_CommonList.html (date of downloading: 28

December 2018).

[4] NATO Standardization Office, The Official NATO Terminology Database, Source: https://nso.nato.int/natoterm/Web.mvc (date of downloading: 17 February 2018).

[5] https://www.act.nato.int/ (date of downloading: 28 December 2018)

[6] C-IED COE: Status, Mission \& Concept, Source: https://ciedcoe.org/index.php/about-cied-coe/status-mission-concept (date of downloading: 04 March 2018).

[7] C-IED COE website, Department Head, Quality Assurance, Source: https://ciedcoe.org/index.php/department-head/quality-assurance-qa (date of downloading: 04 March 2018).

[8] SOAC CCD II (Date: 1 April 2013)

[9] HORVÁTH T.: Az IED hálózat, mint korunk egyik aszimmetrikus kihívása, Source: Csengeri János, Krajnc Zoltán (szerk.) Humánvédelem - békemüveleti és veszélyhelyzet-kezelési eljárások fejlesztése. 791 p. Budapest: Nemzeti Közszolgálati Egyetem, Hadtudományi és Honvédtisztképző Kar, 2016. pp. 275-298. (ISBN: 978615-5305-35-1).

[10] Bi-SC 075-007, Education and Individual Training Directive (E\&ITD), date: 10 September 2015. Source: https://www.act.nato.int/images/stories/structure/jft/ptecs/etd075-007.pdf (date of downloading: 28 December 2018.

[11] STANAG 2116 LO, NATO Codes for Grades of Military Personnel, EDITION 6, 25 February 2010. Source: https://nso.nato.int/protected/nsdd/ CommonList.html (date of downloading: 28 December 2018).

[12] SOAC Instructor Overview_intro v2 May 2011, Handover-takeover presentation from 2011, Source: C-IED COE (date: 5 May 2011).

[13] CIAC CCD II (Date: 20 August 2018).

[14] C-IED COE (S0940-2015) C-IED Discipline Alignment Plan (Date: 28 January 2016).

[15] Education and Training Opportunities Catalogue (ETOC), C-IED Discipline, CSOC course, Source: https://e-

itep.act.nato.int/Guest/ETOCedit.aspx?sEncCrit=z21tSYwJspt7YhJqHCsOnsHrTPWv6 QJwb2em5Y\%2fURhMt5E\%2bbWpPESaRefi4zMP4PJmsbFSn3zEVuNxHPFdjI1\%2f Ob9fWNZ5U\%2fZ9HVgipSMrieog8f4Yx0htcOaUc90rpcbCkcHXTFxiy5YtB9yP7WG h6z2ebhIDe4w3PETWqTE7AKQL6wFCjLyrfxzg7zpdz0jkToPMpoPZUAyEVdwgjrI6 nuhlJgziRfaN\%2bg8\%2f8IX3nHuPxZmLjMHYfc\%2fXb01wfbNqpF5QmXYShyAmZ kisRA4Emyn\%2b\%2fjrs73Uz2WVgTeYL513avMDpOL9gIeWBb5\%2bYGuBCKB7G GmCsuxcR4SZayT\%2fYKEIjkuAK\%2bm9NEcxCiGkyejQsEyDL6mRnUMsmjh1L7n 
Czl7kIgIngrrBHBy7DRydNIjVoAadNfOKQ1LVfMjEaWzi1 J\%2bw\%2b3C6evJmaZtI ZIxf543xEtErHPKaNhS6OTzQa4Yr\%2bW8n7lgFXBrXfOuEtlHDDL89WdMLd\%2fG X\%2bbPu77r (date of downloading: 28 December 2018).

[16] NATO Joint Advanced Distributed Learning website, Source: https://jadl.act.nato.int (date of downloading: 04 March 2018).

[17] TÁBI L.: Távoktatás a C-IED területén, Source: Hadtudományi Szemle, 2018. XI. évfolyam 2. szám, http://archiv.uninke.hu/downloads/kutatas/folyoiratok/hadtudomanyi szemle/szamok/2018/2018 2/18 2 _forum_tabil.pdf (date of downloading: 11 November 2018).

[18] Education and Training Opportunities Catalogue (ETOC), C-IED Discipline, Source: https://e-

itep.act.nato.int/Guest/ETOCindex.aspx?sEncCrit=KTfmWLxPHci\%2bxBaQEhKu2jFx xoJ67NQZ2FdWv\%2fF3Y54W\%2b9LqrZq9J2nt1PiLEYlsqXprdug2U2eNetZF\%2fSW DQViaaH9Rsxd89XxanwjbZGNgZGEm\%2bFk5BQJBBq7KIUXTeIkkUbgsYVdVyT3 RfMdZSUXvFEDDv7MS6DMLmYNQRdwnZhNmk3EbEM8oLiRaTC2pe5PzcVDjg Ylo4RliD8KZEhSRIGBvR13P5IY17X4Z6tYnR76S5gKAoThyZqUxxhEbhJHO6Zlan6 w662EO\%2bICsS3Y5VDV08Zujn3hDn6MO\%2b24CZFqViVsC7J4Xx8413gP92c\%2b a3PvJqAvIJwFtMGoGKg\%3d\%3d (date of downloading: 28 December 2018). 